Egyptian Journal of Aquatic Biology \& Fisheries

Zoology Department, Faculty of Science,

Ain Shams University, Cairo, Egypt.

ISSN $1110-6131$

Vol. 23(3): 1 - 12 (2019)

www.ejabf.journals.ekb.eg

\title{
Nonylphenol ethoxylate (NPE) influence on reproductive performance of male Nile tilapia, Oreochromis niloticus
}

\author{
Amer, M.A., Ahmed, K.M., and Osman, M.F. \\ Anim. Prod. Dept., Fac. of Agric., Ain Shams Univ., P.O. Box 68, Hadayek Shubra, \\ 11241, Cairo, Egypt. \\ Corresponding author: amer_fish@yahoo.com
}

\section{ARTICLE INFO \\ Article History: \\ Received: April 12, 2019 \\ Accepted: May 29, 2019 \\ Online: June 2019}

\section{Keywords:}

Nile tilapia

Oreochromis niloticus

Nonylphenol

Growth performance

liver

GSI

HSI
The aim of the present study was to investigate the effects of xenoestrogens, like nonylphenol (NP) on growth performance and gonads development of male Nile tilapia. Fish were randomly distributed into four groups in 16 fiberglass tanks with carrying capacity of 15 fish/tank and four replicates. Fish were exposed to different concentrations of NP. The contaminations of NP were $0,25,50$ and $100 \mu \mathrm{gL}^{-1}$ administrated for 126 days. After exposure period, fish weight and survival were measured. Gonads and liver were dissected for calculating both Gonado- Somatic Index (GSI) and Hepato- Somatic Index (HSI) and processed for histological examination. At the end of the exposure period in all treated groups, the average survival rate was significantly lower than that of the control. The average body weights were ranged between $73.41 \pm 1.37 \mathrm{~g}-78.14 \pm 6.86 \mathrm{~g}$ for the control

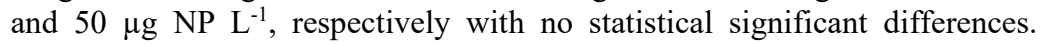
Results showed slight changes in liver weight among treated group compared to the control. A significant $(\mathrm{P}<0.05)$ reduction in gonads weight and GSI occurred in exposed fish compared to the control. Testicular sections from the control group appeared fully mature where, lumens and ducts were loaded with spermatozoa. However, testicular sections from NP exposed fish showed germinal epithelium degeneration, which correlated with exposure level of NP and reflected on low weight of the gonads. The presence of oocytes within the testicular tissue was pronounced, especially in high dose exposed fish.

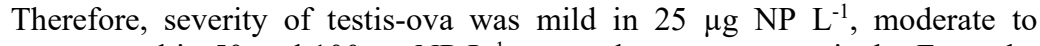

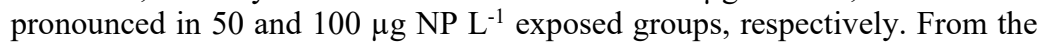
obtained results, it could be concluded that the environmental pollutants with estrogenic activity such as nonylphenol can alter the development of gonads and disrupt reproduction of wild and farmed fish.

\section{INTRODUCTION}

Fish represent a natural and renewable resource; healthy stocks can sustain a reasonable level of exploitation, but for this they need a healthy environment. Unfortunately, both marine and freshwater fish populations are facing the risk of hazardous substances; among these are antifouling treatments, endocrine disrupters, radioactive substances, nutrient pollution and consequences of shipping activities, including oil spills and ballast water discharges (OSPAR, 2000). Moreover, BinDohaish (2012) mentioned that synthetic products such as bisphenol A, polychlorinated bisphenol, dioxins, phthalates, pesticides, heavy metals, 
alkylphenols, polycyclic aromatic hydrocarbons, ethinyl-estradiol and estradiol, among others compounds, the seepage from sewage water to aquatic environments are associated with the observed changes in secondary sex characteristics of male and female fish. Additionally, there are other significant effects, which can be observed in fish, these include the reduction of reproductive hormones levels (i.e., estrogens and androgens), inhibition of gonadal growth, appearance of the female egg proteins (vitellogenin; VTG) in male fish blood, gonadal histopathology and even intersex fish containing "testes-ova" (Jobling et al., 2002). Reproductive and parental behavior alteration and impairment in olfactory response and disorder in reproductive migrations has been also mentioned by Scholz et al. (2000) and disruption in coordinating courtship behavior of male and female fish and time of spawning (Jaensson et al., 2007).

Those alterations, regarding these toxic agents have been noted in several fish populations and species such as Japanese medaka (Oryzias latipes), cunner (Tautogolabrus adspersus), winter flounder (Pleuronectes Pseudopleuronectes americanus), male roach (Rutilus rutilis), salmon (Salmo salar), walking catfish (Clarias batrachus), freshwater eel (Monopterus albus) (Moore and Waring, 2001; Balch and Metcalfe, 2006; Khan, 2013). Testis-ova have been induced experimentally by wide variety of chemicals that mimic estrogen effect such as, NPEs, bisphenol A and endocrine disrupting chemicals (EDC) such as, DDT, endosulfan, methoxychlor, malathion, diazinon, fenitrothion (Mahdi, 2012); and Odum et al. (1997) showed that alkyl phenols including nonylphenol (NP) and nonylphenol ethoxylate (NPE) family in laboratory was mimicking the effects of estrogen in vitro and in vivo studies. Consequently, the main objective of the percent study was to detect the reproductive alteration on male Nile tilapia, Oreochromis niloticus caused by long-term exposure to xenoestrogen, NP, such an environmental pollutant.

\section{MATERIALS AND METHODS}

The experiment was carried out in a static water system of Fish Production Branch, Department of Animal Production, Faculty of Agriculture, Ain Shams University, Cairo, Egypt. The experimental duration was 126 days. Sixteen quadrate fiberglass tanks $(60 \times 30 \times 60 \mathrm{~cm})$ were used. The debris and solid wastes were removed every 48 hours by siphon, the siphoned water was compensated and adjusted to keep a fixed amount of exposure dosage in all treated tanks. Water in the experimental tanks was continuously aerated using a simple electric air blower. The experimental tanks were maintained under a $12 \mathrm{~h} \mathrm{~L}: 12 \mathrm{~h}$ D photoperiod. The water temperature and oxygen saturation were measured daily at 8.00 am by oxygen meter (Lutron model Do-5509, Taiwan); while the $\mathrm{pH}$ values were determined by digital $\mathrm{pH}$ meter (Hanna model PHEP, USA). Water parameters were maintained according to the following criteria: average water temperature $27 \pm 2^{\circ} \mathrm{C}$, dissolved oxygen 5-6 mg $\mathrm{L}^{-1}, \mathrm{pH} 7.4$, whereas total ammonia and nitrite levels were neglected due to the continuous water change regime.

\section{The experimental Fish}

The experimental fingerlings of Nile tilapia, O. niloticus, were purchased from a private fish hatchery in El-Sharqiyah Governorate, Egypt and were transported in plastic bags to the wet lab of fish rearing units. Fingerlings were fed a commercial floated tilapia feed (27\% crude protein) 2 times a day at 8 am and $4 \mathrm{pm}$ and were kept in tanks for 15 days as an adaptation period. The amount of feed/day was calculated 
as percentage of the total biomass/tank according to tilapia feeding tables adopted from Delong et al. (2009). Thereafter, fish were manually sexed, and all male fish (240) were randomly distributed into three treatments plus the control group. Each experimental group was represented by four replicates in 16 fiberglass tanks with carrying capacity of 15 fish/tank; the average individual weight for the experimental fish were $17.1 \mathrm{~g}$.

\section{Chemicals}

Commercial grade of nonylphenol (nonylphenol ethoxylate) were purchased from a local commercial chemical's provider. The commercial grade name "TERGITOL (TM) NP-9 Surfactant" trademark produced by Dow Company, USA. Contamination dosages were calculated according to the information given by the company product data sheet. Nonylphenol ethoxylate (NPE) was diluted to 25,50 and $100 \mu \mathrm{gL}^{-1}$ in the experimental tanks rearing water. All glassware was washed with distilled water and heated in a muffle furnace at $>450^{\circ} \mathrm{C}$ in order to reduce background contamination (Webster et al., 2013).

\section{Fish samples and measurements}

The initial biomass weight in all tanks was recorded at the beginning of the experiment. Fish body weight was taken biweekly and were recorded throughout the experimental period for each tank. Thereafter, the fish was returned to their experimental tanks. Ten males from each tank were taken at the end of the experiment and anesthetized by dipping in 40-liter tank containing $0.1 \%$ Quinaldine for morphological measurements; fish total body weight and fish total length and for dissection procedure. Testes and liver were taken from the body cavity and were dried on filter paper and weighed on a digital balance. Thereafter, the gonadosomatic index (GSI) and hepatosomatic index (HSI) were calculated.

\section{Histological characteristics}

The fish gonads were removed, dissected into small pieces and fixed in Davidson's modified solution, then dehydrated through a series of ascending concentrations of ethanol, cleared with xylene solutions, embedded and blocked in paraffin wax according to Genten et al. (2009). Fine transverse sections $5 \mu$ were cut, mounted and stained with hematoxylin and eosin according to Johnson et al. (2010). The tissue slides were examined by light microscope and photographed by fluorescence microscope Leica DM2500, Germany. Testicular sections were examined and classified into distinct spermatogenic stages according to the most existence of germ cells type in the tissue, which were used as reproductive biomarker of gonadal staging adopted by Kosai et al. (2011).

\section{Statistical analysis}

All numerical data were statistically analyzed by one-way ANOVA according to the following model;

$Y_{i j}=u+T_{i}+e_{i}$; where $Y_{\mathrm{ij}}$ is the observation; $\mathrm{u}$ is the overall mean; $T_{\mathrm{i}}$ is the effect of treatment, and $\mathrm{e}_{\mathrm{i}}$ is the random error.

In all cases, significance was accepted at $(P<0.05)$, where statistical analysis was performed using SAS (1998).

\section{RESULTS AND DISCUSSION}

\section{Growth performance and survival rate}

Fish survival rate was monitored daily in all experimental individuals after the administration of NP. The average survival rate at the end of the experiment in all exposed groups specially those exposed to high doses were significantly lower than 


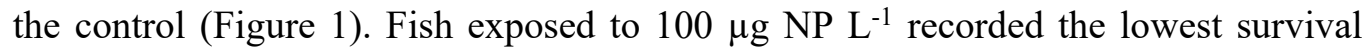

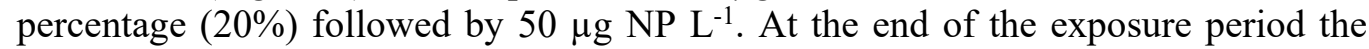
average body weights were almost similar in all exposed and non-exposed fish recording $73.41 \pm 1.37 \mathrm{~g}$ and $78.14 \pm 6.68 \mathrm{~g}$ for the control and $50 \mu \mathrm{gL}^{-1}$ treated fish, respectively. It was inferred from the present data that doses up to $100 \mu \mathrm{g} \mathrm{NP} \mathrm{L}^{-1}$ had no effect $(\mathrm{P}>0.05)$ on growth performance parameters (Figure 2$)$. The findings of Balch and Metcalfe (2006) were close to the present data, which indicated that fish survival during a period of 100-day exposure to NP was greater than $70 \%$ in all treatments, excluding those tested at $1000 \mu \mathrm{gL}^{-1}$ of nonylphenol ethoxylates (NPEO). Survival was only $20 \%$ in the $1000 \mu \mathrm{g}$ NP4EO L ${ }^{-1}$ treatment and $100 \%$ mortality

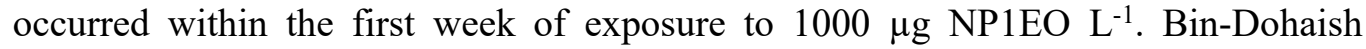
(2012) reported that the numbers of dead $O$. spilurs were within a normal range and all fish were healthy throughout the experimental period (July - December) after exposed to 15 and $30 \mu \mathrm{gL}^{-1}$ of NP.

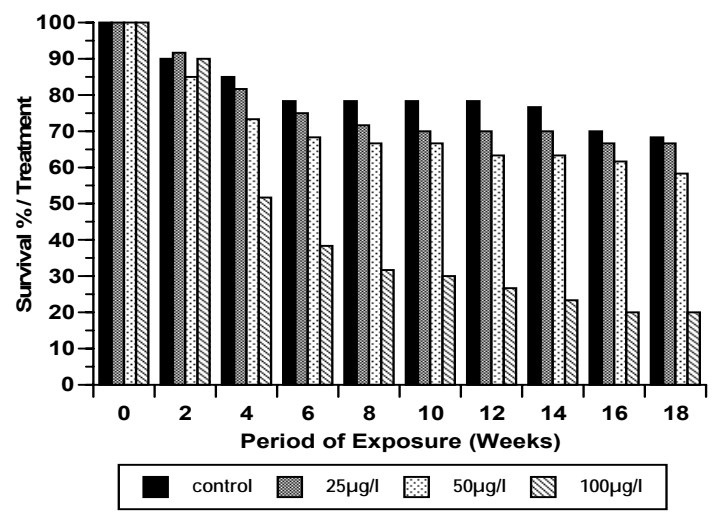

Fig. 1: Fortnightly average survival rate of Oreochromis niloticus exposed to different doses of NP during experimental period.

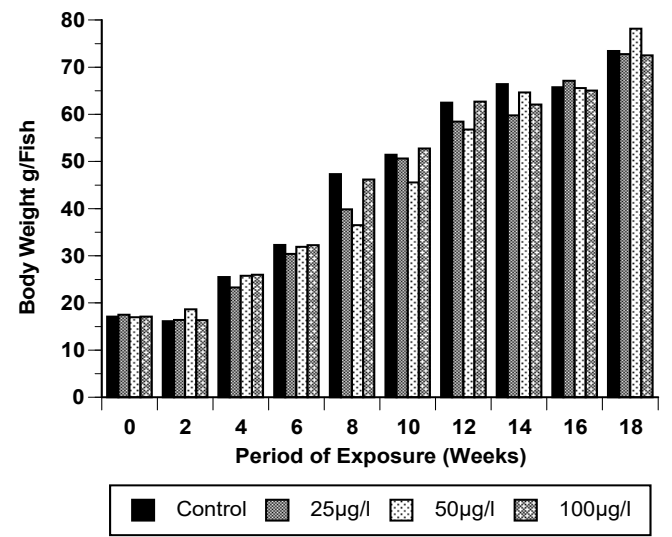

Fig. 2: Fortnightly average body weight of Oreochromis niloticus exposed to different doses of NP during experimental period.

Conversely, Bin-Dohaish (2008) reported significant increase in body weight and length in 15 and $30 \mu \mathrm{gL}^{-1} \mathrm{NP}$ exposed adult tilapia, Oreochromis spilurs compared to the control and low dose $\left(3.5 \mu \mathrm{gL}^{-1}\right)$ treated fish, and no mortality was recorded during the exposure period (30 days). In rainbow trout (Oncorhynchus

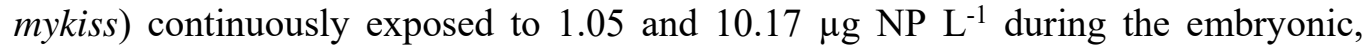
larval and juvenile life stage for 1 year, no mortality and no influence on the body weight of 1-year-old fish were recorded (Ackermann et al., 2002). In Nile tilapia, the mortality rate reached $40 \%$ after 7 days' exposure to $500 \mu \mathrm{gL}^{-1} \mathrm{NP}$ and $13.34 \%$ after 10 days from stopping exposure to NP (Ismail and Mahboub, 2016). In recent study carried out on zebrafish by Sun et al. (2017) showed that NP can behave as a strong estrogen agonist at environmentally-relevant concentrations. The estrogenic effect of NP potentially disrupted the growth and sexual differentiation of zebrafish. A significant decrease $(\mathrm{p}<0.05)$ in the length was observed in zebrafish exposed to 200 $\mu \mathrm{gL}^{-1}$ of NP for 125- and 140-days post-fertilization.

\section{Liver weight and HSI}

Statistical analysis showed that the liver weight and HSI were significantly affected by NP treatment at $(P<0.05)$. Results showed slight changes in liver weight among treated group compared to the control. The liver weight in treated groups

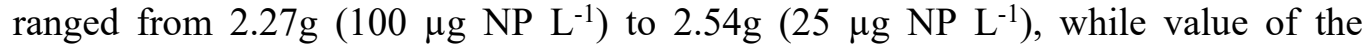


control group was $1.85 \mathrm{~g}$. The highest value of HSI (3.20) was recorded in fish group exposed to $25 \mu \mathrm{g} \mathrm{NP} \mathrm{L}{ }^{-1}$ compared to the control (2.74). However, the values of HSI were slightly lower in $100 \mu \mathrm{gL}^{-1}$ and $50 \mu \mathrm{gL}^{-1}$ of NP exposed groups. These findings agree with those obtained by Lenhardt et al. (2009) who mentioned that, HSI is associated with liver energetic reserves and metabolic activity. Thus, the condition of the liver and the whole body measured with the hepatosomatic index value, can provide information on potential pollution impacts. Although such parameters are not very sensitive, they may serve as an initial screening biomarker to indicate the exposure effects. The HSI value was high during the beginning of preparatory phase and gradually declined to lower levels in the prespawning phase. The correlation between HSI and GSI in bronze featherback (Notopterus notopterus) indicates inverse relationship (Saeed, 2013 and Sadekarpawar and Parikh, 2013). Such rhythm of changes has been reported in some other fishes such as Heteropneustes fossilis and suggested that hepatic tissue store large amount of nutrients, which is a common morphologic response of fish liver to stresses (spawning and reproduction) that enhance utilization of glycogen as an immediate energy source to meet the energy demand during spawning seasons. These findings agree with the findings of Harris et al. (2001) who indicated that exposure to $85.6 \mu \mathrm{gL}^{-1}$ of nonylphenol for 18 weeks on rainbow trout $O$. mykiss resulted in reduction of GSI, HSI, induced vitellogenin, lowering plasma estradiol and plasma FSH. Moreover, Goksøyr et al. (2003) mentioned that the direct consequences of vitellogenin (VTG) and zona radiata protein (Zrp) synthesis in males may include reduced calcium in the skeleton and scales, liver hypertrophy and kidney damage. It has been demonstrated also that estrogenic effects may cause organ toxicity, particularly in liver and gonads.

Ma et al. (2005) reported that the HSI values of males Japanese medaka, Oryzias latipes, increased significantly when exposed to $5 \%, 10 \%$ and $20 \%$ of secondary treated sewage effluent, values were 4.17, 4.48 and 4.69, respectively compared to the control (3.75). However, at exposure concentration of $40 \%$ and higher, there was a decrease of HSI values resulting mainly from the rapid decrease of body weight. The authors added that the decrease of HSI value exposed to high concentrations of the effluents may be caused by sub-lethal toxicity of the effluent and could be proved in the pathologic observation of liver. The grossly visible lesions of the liver, presented as the slight white other than the normal orchid, occurred at concentration of $40 \%$. Variation of HSI at higher concentrations of effluent could be the joint effects of loss of body weight and liver intoxication. Ismail and Mahboub (2016) reported severe degenerative changes in the hepatic tissues as represented by vacuolation of the hepatic cells, telangiectasia, and hepatopancreatic necrosis, kidney dysfunction with marked vacuolation in the epithelium of the renal tubules and the appearance of shrunken glomeruli in Nile tilapia exposed to $500 \mu \mathrm{g} \mathrm{NP} \mathrm{L}{ }^{-1}$. In addition, Uguz et al. (2003) pointed that exposing to $220 \mu \mathrm{gL}^{-1}$ of nonylphenol for 4 weeks on rainbow trout $O$. mykiss resulted in liver tissue hemorrhage and lymphocyte infiltration.

\section{Gonads weight and GSI}

The control group had the highest gonads weight $0.63 \mathrm{~g}$, while values among the treated groups, were $0.61 \mathrm{~g}$ and $0.53 \mathrm{~g}$ in groups exposed to $50 \mu \mathrm{gL}^{-1}$ and $25 \mu \mathrm{gL}^{-1}$ of $\mathrm{NP}$, respectively, while the lowest value $(0.47 \mathrm{~g})$ was recorded for fish exposed to 100 $\mu \mathrm{gL}^{-1}$. On the other hand, the highest value of GSI was recorded in the control (0.95), whoever, the lowest value $(0.50)$ was recorded in $100 \mu \mathrm{gL}^{-1} \mathrm{NP}$ exposed group. Statistical analysis of gonads weight and GSI revealed that NP at high doses caused significant $(P<0.05)$ reduction in GSI between exposed fish groups and the control. 
Gimeno et al. (1998) in mature male common carp, Cyprinus carpio, exposed for 3month period to sublethal concentrations $32,100,320$ and $1000 \mu \mathrm{gL}^{-1}$ of 4-tertpentylphenol (pseudo-estrogen, TPP); 0.1 and $1 \mu \mathrm{gL}^{-1}$ of $17 \beta$-Estradiol $\left(\mathrm{E}_{2}\right)$ during spermatogenesis, reported that after a 1-, 2- and 3-month exposure, the gonadal weight (expressed as GSI) was only significantly reduced in individuals exposed to the high $\mathrm{E}_{2}$ concentration. In most sampling periods, there was a large variability in the GSI of individuals from the same treatment. Therefore, the effects caused by TPP were less pronounced, and were not manifest until the end of the 3-month experiment, when almost all TPP concentrations caused a significant decrease in the GSI down to 25 to $65 \%$ of the controls. The average GSI of carp exposed to the highest dose of TPP was 0.87, a similar value to the average GSI of the fish exposed to the highest dose of $\mathrm{E}_{2}(0.58)$, whilst, at lower concentrations of $\mathrm{E}_{2}$ and TPP, testicular growth was retarded to a much lesser degree.

In male Japanese medaka, O. latipes, the GSI values decreased when concentration of effluent was higher than 5\%. The decrease of GSI with dilutions of effluent was in a dose dependent manner due to its estrogenic effects. Values of GSI recorded were $1.37,1.22,1.14,0.91,0.89,0.83$ for males treated with different dilutions $(0,5,10,20,40,50)$ of secondary treated sewage effluent or $100 \mathrm{ngL}^{-1} \mathrm{E}_{2}$ (0.51), respectively. The data suggested that the effluents could inhibit the growth of gonads of medaka and males are more sensitive to effluent than females (Ma et al., 2005). Gonadosomatic index in sexually mature male $O$. spilurs showed significant decrease after exposed to aqueous solution of 4-NP at concentrations of 15, and 30 $\mu \mathrm{gL}^{-1}$ for a month compared to low dose exposed group $\left(3.5 \mu \mathrm{gL}^{-1}\right)$ and the control (Bin-Dohaish, 2008). Values of GSI were 0.49, 0.52, 0.92 and 1.06 for 15, 30, 3.5 $\mu \mathrm{gL}^{-1}$ of 4-NP and the control group, respectively. The author mentioned 3 -fold increase in plasma concentrations of endogenous estrogen greater in males of pairbreeding fathead minnows (Pimephales promelas) exposed to 4-NP and significant decrease in testosterone levels compared to those of the control group. In accordance with the present study the GSI in males exposed to $100 \mu \mathrm{g}$ NP $\mathrm{L}^{-1}$ were $46 \%-62 \%$ reduction than of the control (Harries et al., 2000).

\section{Histological observation of the testis}

Transverse testicular sections from the control group illustrate that testis appeared normally in its architecture and fully mature as pronounced by the presence of spermatozoa in the lobular lumens and sperm ducts, although some spermatogenetic cysts are existed specially at testis periphery (Figures 3 and 4).

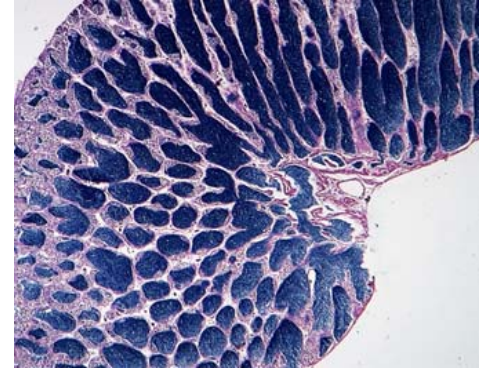

Fig. 3: Photomicrograph of $5 \mu$ testicular transverse section of mature $O$. niloticus stained with H\&E 10X, control group showing normal testis filled with spermatozoa.

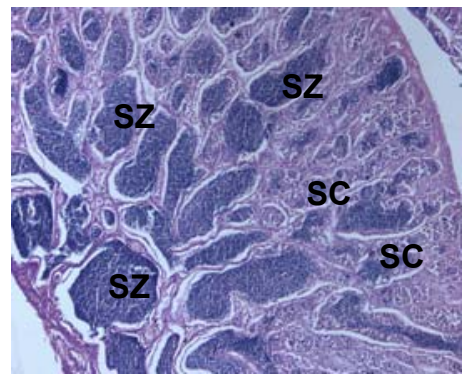

Fig. 4: Photomicrograph of $5 \mu$ testicular transverse section of $O$. niloticus stained with H\&E 20X; control group, spermatogenetic cysts (SC) and Spermatozoa (SZ). 
After 126 days' exposure, the general aspect of the testes from the individuals exposed to lower concentration of NP were less developed with lesser abundance of spermatogenic cysts despite, the presence of all spermatogenetic cyst types and the presence of abundant islets of hypertrophied Leydig cells (Figure 5). Testicular sections from males exposed to higher dose of NP $\left(50 \mu \mathrm{gL}^{-1}\right)$ showed regressed testes with shrinkage of seminiferous lobules, degeneration of germinal epithelium and the absence of spermatozoa (Figure 6).

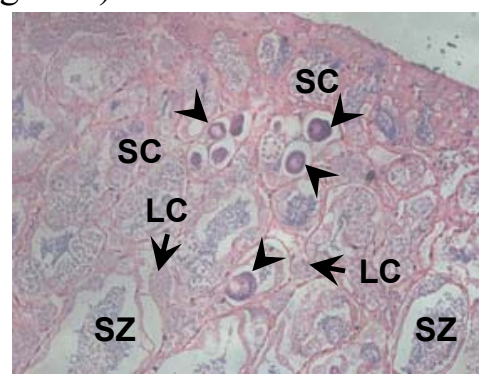

Fig. 5: Photomicrograph of $5 \mu$ testicular transverse section of $O$. niloticus exposed to $25 \mu \mathrm{gl}^{-1} \mathrm{NP}$ stained with H\&E 20X, showed less developed seminiferous lobules with lesser abundance of spermatogenic cysts, despite the presence of all germ cell cysts (SC) including spermatozoa (SZ). Note, the presence of abundant islets of hypertrophied Leydig cells (LC) and scattered pre-vitellogenic oocytes (arrowheads) within seminiferous lobules.

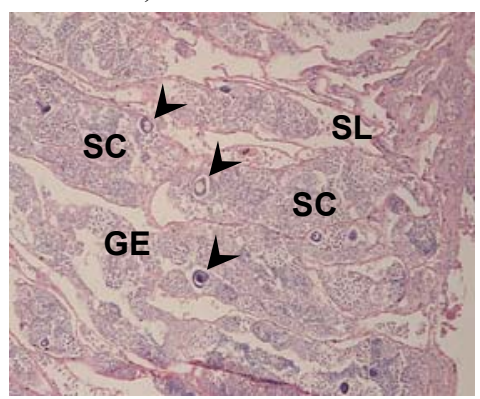

Fig. 6: Photomicrograph of $5 \mu$ testicular transverse section of $O$. niloticus exposed to $50 \mu \mathrm{gl}^{-1} \mathrm{NP}$ stained with H\&E 10X, showed regressed testes, degeneration of germinal epithelium (GE), absence of spermatozoa and shrinkage of some seminiferous lobules (SL). Note, scattered previtellogenic oocytes (arrowheads) were existed in seminiferous lobules.

More severe changes, such as disorganization of the lobules, atrophy of germinal epithelium, absence of spermatozoa and necrotic germ cells, were observed in the testes of the highest dose of NP exposed fish, these findings were accompanied by hypertrophy and hyperplasia of Leydig cells (Figure 7). Testes of some individuals developed vacuoles as well as fibrous around the seminiferous lobules.

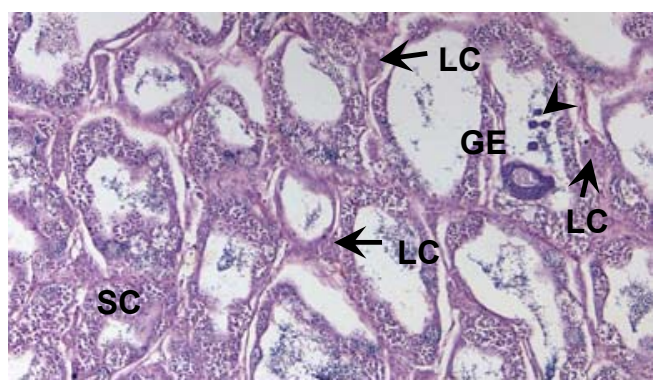

Fig. 7: Photomicrograph of $5 \mu$ testicular transverse section of $O$. niloticus exposed to $100 \mu \mathrm{gl}^{-1} \mathrm{NP}$ for 126 days stained with H\&E 20X, showed regressed testis with abnormal architecture, atrophy of germinal epithelium (GE), hypertrophied Leydig cells (LC) and the lobular lumines are almost empty of spermatozoa. Note, scattered oogonia (arrowheads) were existed in seminiferous lobules. 
From the histological examination of testicular sections, it was inferred that due to the empty testicular lumens in the histological sections from $100 \mu \mathrm{gL}^{-1}$ exposed fish, which reflect degenerative activity of the testes and caused low GSI compared to control males. While, in 25-50 $\mathrm{gL}^{-1}$ exposed male fish, there was faint presence for spermatozoa cysts, so it had retained the high GSI values compared to that of higher dose. Our observations are supported by the findings of Jobling et al. (1996) who pointed that histological examination of the testes in the control group showed that fish developed active testes with predominance of spermatozoa. The fish exposed to nonylphenol had a significantly higher proportion of spermatogonia type A than controls and showed statistically significant reductions in testis size, expressed as GSI. Kinnberg et al. (2000) suggested that, exposure to NP or E2 resulted in a reduction in the number of cysts containing different stages of spermatogenetic cells, in these fish, spermatogenesis must be expected to be almost totally impaired. On the other hand, increased number of hypertrophied Sertoli cells, which were not incorporated in the efferent duct epithelium, was also observed in the treated male platyfish, Xiphophorus maculatus. The sperm ducts of fish exposed to high concentrations of NP or to $\mathrm{E}_{2}$ were free of spermatozoa, which may be due to incomplete formation of the spermatozoa before extrusion into the efferent ducts. Therefore, the changes observed after exposure to high concentrations of NP or to $\mathrm{E}_{2}$ strongly indicate that these compounds are capable of decreasing male fertility in $X$. maculatus. Kaptaner and Ünal (2011) noted that, despite germ cell apoptosis and fibrosis, presence of testis-ova was observed in testis tissue after chronic exposure to environmental estrogens $\left(\mathrm{EE}_{2}\right)$ and NP. Results also showed that EE2 and NP are capable of producing estrogenic responses besides germ cell death and fibrosis in the testis of Chalcalburnus tarichi eventually lead to testicular regression. Furthermore, El-Dakdoky and Helal (2007) observed that estrogenic effects have been affirmed to cause organ toxicity associated with oxidative stress, especially in two of the most dynamic organs liver and gonads.

Exposure of tilapia to NP4 caused vitellogenin (VG) induction in males, a process normally dependent on endogenous estrogen $\left(E_{2}\right)$ and was correlated with testicular regression (Bin-Dohaish, 2008). The author mentioned that, plasma concentrations of endogenous $\mathrm{E}_{2}$ was 3 -fold greater in $15 \mu \mathrm{g} \mathrm{L}^{-1} \mathrm{NP}$ exposed males than those of the control. Whereas, a highly significant decrease in plasma testosterone level was detected in exposed males $\left(30 \mu \mathrm{g} \mathrm{L}{ }^{-1} \mathrm{NP}\right)$ than that of control. These hormonal disruption lead to reduction of seminiferous lobules, interrupt cyst formation, decrease in spermatids and spermatozoa accompanied by increase of interstitial fibrous connective tissue, and widening of interstitial space. Moreover, Leydig cells appear hypertrophied with vacuolated cytoplasm and necrotic nuclei. The appearance of testis-ova was recorded in individuals exposed to high dose (30 $\mu \mathrm{g}$ NP L ${ }^{-1}$ ). Similar observations were recently reported by Ismail and Mahboub (2016) in tilapia O. niloticus males exposed to $500 \mu \mathrm{g} \mathrm{L}^{-1} \mathrm{NP}$ for 7 days. The authors revealed significant decrease in serum testosterone level compared with unexposed male fish. They suggested that this decrease could be due indirect act of NP on hypothalamus-pituitary axis to alter synthesis and secretion of gonadotropin leading to interrupt of sex steroid production, or by its direct acts on the testicular cell either through cytotoxic effect on germ cells, or by disrupting Sertoli cells endocrine function, results in testis damage and endocrine malfunction.

Scattered pre-vitellogenic oocytes were observed in some individuals of all concentrations exposed fish (Figures 5, 6 and 7). In addition, 'nests' of previtellogenic oocytes were observed either within or between seminiferous lobules of 
regressed testes, especially in the higher NP exposed fish (Figures $8 \mathrm{~A}$ and B), these gonads were identified as early testis-ova.
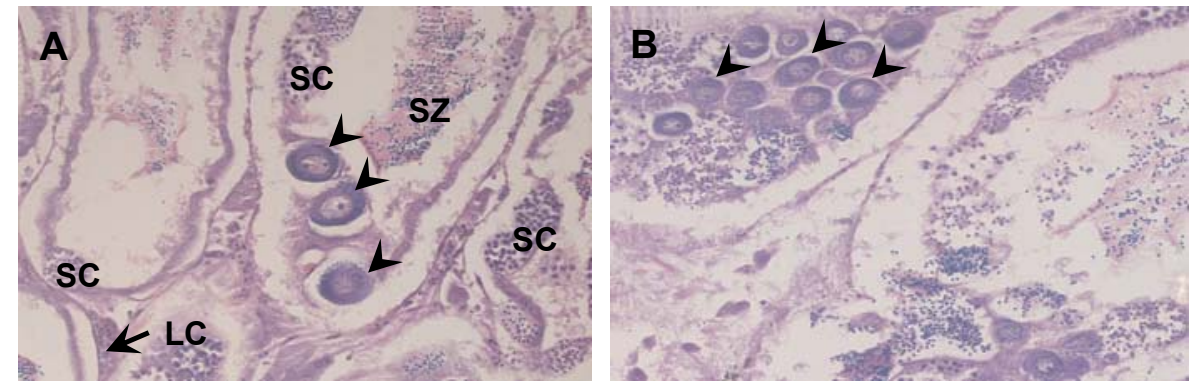

Fig. 8: Photomicrograph of $5 \mu$ testicular transverse section of $O$. niloticus exposed to $100 \mu \mathrm{g} \mathrm{L}^{-1} \mathrm{NP}$ for 126 days stained with H\&E 20X, showed regressed testis with a few spermatogenic cysts (SC). Despite the presence of spermatozoa (SZ), pre-vitellogenic (arrowheads) were existed in seminiferous lobules (A). Some lobules contained 'nests' of pre-vitellogenic oocytes (arrowheads) in the regressed testes, these gonads were identified as early testis-ova (B).

Similar findings were recorded by (Balch and Metcalfe, 2006) who mentioned that gonadal intersex is characterized by the presence of pre-vitellogenic oocytes within the testes of male medaka (i.e., "testis-ova"). Histological section of the testis of male medaka after 100 continuous days of exposure to nonylphenol $\left(100 \mu \mathrm{gL}^{-1}\right)$ showing testis-ova characterized by the presence of pre-vitellogenic oocytes distributed among disorganized spermatocytic cysts. The treatment with $100 \mathrm{\mu gl}^{-1} \mathrm{NP}$ induced gonadal intersex in over $80 \%$ of exposed males, whoever, only one of the 22 phenotypic male fish exposed to the lower concentration $\left(30 \mu \mathrm{g} \mathrm{L}^{-1} \mathrm{NP}\right)$ exhibited gonadal intersex. The number of pre-vitellogenic oocytes within a section of intersex gonadal tissue varied from a low of one to $>20$. The majority of tissues had at least five oocytes in individual sections prepared from the testis.

The present results indicated that concentrations of $25-100 \mu \mathrm{g} \mathrm{L}^{-1} \mathrm{NP}$ treatment were clearly estrogenic as evidenced by the induction of testis-ova. The induction of intersex at concentrations of 25 and $100 \mathrm{\mu L}^{-1}$ is consistent with earlier study by Gray and Metcalfe (1997) that showed induction of testis-ova in Japanese medaka exposed for 3 months to NP concentrations of 50 and $100 \mu \mathrm{gL}^{-1}$. The incidence of such a case was six out of twelve males (50\%) and six out of seven males $(86 \%)$ in the $50 \mu \mathrm{gL}^{-1}$ and $100 \mu \mathrm{gL}^{-1}$ exposed fish, respectively. No incidence of testis-ova was found neither in the control group nor in $10 \mu \mathrm{gL}^{-1}$ exposed fish. Sex ratio in the multigeneration exposed to NP was affected, where the proportion of females accounted for $80 \%$ (36 females) in $20 \mu \mathrm{gL}^{-1}$ of NP, however, treatment with $2 \mu \mathrm{gL}^{-1}$ and 200 $\mu \mathrm{gL}^{-1}$ did not show any significant difference from the control (Sun et al., 2017). In Contrary, rainbow trout (Oncorhynchus mykiss) exposed to 1.05 and $10.17 \mu \mathrm{g} \mathrm{NP} \mathrm{L}^{-1}$ from the egg stage until 1 year of age did not induce testis-ova or lead to alter the sex ratios when compared with the control group (Ackermann et al., 2002). The induction of VG and zona radiata protein (ZRP) expression was a more sensitive reaction to the presence of NP than the formation of testis-ova and the reversal of sex.

\section{CONCLUSION}

Based on the obtained results herein, it could be concluded that the environmental pollutants with estrogenic activity like nonylphenol (NP) found in sewage treatment effluents and surface water at low concentrations have the potential 
to alter gonadal development and reproduction of wild and farmed fish. Combination of multi estrogenic pollutants, endocrine disrupting chemical, may add adverse effects. Hence, it is possible that nonylphenol, either by itself or through its contribution to the pool of environmental pollutants have harmful effects on the reproductive performance of fish.

\section{REFERENCES}

Ackermann, G.E.; Schwaiger, J.; Negele, R.D. and Fent, K. (2002). Effects of long-term nonylphenol exposure on gonadal development and biomarkers of estrogenicity in juvenile rainbow trout (Oncorhynchus mykiss). Aquatic Toxicology, 60: 203-221.

Balch, G. and Metcalfe, C. (2006). Developmental effects in Japanese medaka (Oryzias latipes) exposed to nonylphenol ethoxylates and their degradation products. Chemosphere, 62: 1214-1223.

Bin-Dohaish, E.A. (2008). Effects of environmental pollution with Alkylphenol (4-nonyl phenol) on reproduction of tilapia, Oreochromus spilurs (teleosts). Egypt. Aquat. Res., 34 (2): 336-355.

Bin-Dohaish, E.A. (2012). The effects of 4-nonylphenol contamination on livers of Tilapia fish (Oreochromus spilurs) in Jeddah. Biol. Res., 45:15-20.

Delong, D.P.; Thomas, M.L. and James, E.R. (2009). Tank Culture of Tilapia. Southern Regional Aquaculture Center (SRAC), Publication No. 282.

El-Dakdoky, M.H. and Helal, M.A.M. (2007). Reproductive toxicity of male mice after exposure to nonylphenol. Bulletin of Environmental Contamination Toxicology, 79: 188-191.

Genten, F.; Terwinghe, E. and Danguy, A. (2009). Atlas of Fish Histology, $1^{\text {st }}$ Ed., pp. 219, Science Publishers, Enfield, NH, USA.

Gimeno, S.; Komen, H.; Jobling, S.; Sumpter, J. and Bowmer, T. (1998). Demasculinisation of sexually mature male common carp, Cyprinus carpio, exposed to 4-tert-pentylphenol during spermatogenesis. Aquatic Toxicology, 43: 93-109.

Goksøyr, A.; Arukwe, A.; Larsson, J.; Cajaraville, M.P.; Hauser, L.; Nilsen, B.M.; Lowe, D. and Matthiessen, P. (2003). Molecular/Cellular Processes and the Impact on Reproduction. In: "Effects of Pollution on Fish: Molecular Effects and Population Responses.” Andrew, J.L. \& Krystal, H. (Eds.). Blackwell Science Ltd., pp.179220.

Gray, M.A. and Metcalfe, C.D. (1997). Induction of testis-ova in Japanese medaka (Oryzias latipes) exposed to p-nonylphenol. Environmental Toxicology Chemistry, 16: 1082-1086.

Harries, J.E.; Runnalls, T.; Hill, E.; Harris, C.A.; Maddix, S.; Sumpter, J.P. and Tyler C.R. (2000). Development of a reproductive performance test for endocrine disrupting chemicals using pair-breeding fathead minnows (Pimephales promelas). Environmental Society of Technol., 34: 3003-3011.

Harris, C.A.; Santos, E.M.; Janbakhsh, A.; Pottinger, T.G.; Tyler, C.R. and Sumpter, J.P. (2001). Nonylphenol affects gonadotropin levels in the pituitary gland and plasma of female rainbow trout. Environmental Society of Technol., 35:2909-2916.

Ismail, H.T.H and Mahboub, H.H.H. (2016). Effect of acute exposure to nonylphenol on biochemical, hormonal, and hematological parameters and muscle tissues residues of Nile tilapia, Oreochromis niloticus. Veterinary World, 9(6): 616-625.

Jaensson, A.; Scott, A.P.; Moore, A.; Kylin, H. and Olsén, K.H. (2007). Effects of a pyrethroid pesticide on endocrine responses to female odours and reproductive behaviour in male parr of brown trout (Salmo trutta L.). Aquatic Toxicology, 81: $1-9$. 
Jobling, S.; Beresford, N.; Nolan, M.; Rodgers-Gray, T.P.; Tyler, C.R. and Sumpter, J.P. (2002). Altered sexual maturation and gamete production in wild roach (Rutilus rutilus) living in rivers that receive treated sewage effluents. Biol. Reprod., 66: 272-281.

Jobling, S.; Sheanan, D.; Julia, A.; Osborne, J.A.; Matthiessen, P. and Sumpter, J.P. (1996). Inhibition of testicular growth in rainbow trout (Oncorhyncus mykiss) exposed to estrogenic alkylphenolic chemicals. Environmental Toxicology Chemistry, 15:194-202.

Johnson, R.; Wolf, J. and Braunbeck, T. (2010). OECD, Guidance document for the diagnosis of endocrine-related histopathology of fish gonads. Series on Testing and Assessment, No. 123, pp. 114.

Kaptaner, B. and Ünal, G. (2011). Effects of 17 $\alpha$-ethynylestradiol and nonylphenol on liver and gonadal apoptosis and histopathology in Chalcalburnus tarichi. Environ. Toxicol., 26: 610-622.

Khan, R.A. (2013). Effects of Polycyclic Aromatic Hydrocarbons on Sexual Maturity of Atlantic cod, Gadus morhua, Following Chronic Exposure. Environment and Pollution, 2(1): 1-10.

Kinnberg, K.; Korsgaard, B.; Bjerregaard, P. and Jespersen, A. (2000). Effects of nonylphenol and 17beta-estradiol on vitellogenin synthesis and testis morphology in male platyfish Xiphophorus maculatus. J. Exp. Biol., 203(2):171-181.

Kosai, P.; Jiraungkoorskul, W.; Sachamahithinant, C. and Jiraungkoorskul, K. (2011). Induction of testis-ova in Nile tilapia (Oreochromis niloticus) exposed to 17ßestradiol. Natural Science, 3(3): 227-233.

Lenhardt, M.; Jarić, I.; Cakić, P.; Cvijanović, G.; Gačić, Z. and Kolarević, J. (2009). Seasonal changes in condition, hepatosomatic index and parasitism in sterlet (Acipenser ruthenus L.). Turk. J. Vet. Anim. Sci., 33(3): 209-214.

Ma, T.; Wan, X.; Huang, Q.; Wang, Z. and Liu, J. (2005). Biomarker responses and reproductive toxicity of the effluent from a Chinese large sewage treatment plant in Japanese medaka (Oryzias latipes). Chemosphere, 59: 281-288.

Mahdi, B. (2012). Adverse Effect of Insecticides on Various Aspects of Fish's Biology and Physiology. In: "Insecticides - Basic and other Applications". Soloneski, S. (Ed.). Intechopen. com, pp. 101-126.

Moore, A. and Waring, C.P. (2001). The effects of a synthetic pyrethroid pesticide on some aspects of reproduction in Atlantic salmon (Salmo salar L.). Aquatic Toxicology, 52: 1-12.

Odum, J.; Lefevre, P.A.; Tittensor, S.; Paton, D.; Routledge, E.J.; Beresford, N.A.; Sumpter, J.P. and Ashby, J. (1997). The rodent uterotrophic assay: critical protocol features, studies with nonyl phenols, and comparison with a yeast estrogenicity assay. Regulatory Toxicology and Pharmacology, 25: 176-188.

OSPAR Quality Status Report (2000). OSPAR Commission for the Protection of the Marine Environment of the North-East Atlantic. OSPAR Commission, London, pp. 108.

Sadekarpawar, S. and Parikh P. (2013). Gonadosomatic and Hepatosomatic Indices of Freshwater Fish Oreochromis mossambicus in Response to a Plant Nutrient. World Journal of Zoology, 8(1): 110-118.

Saeed, S.M. (2013). Impact of environmental parameters on fish condition and quality in Lake Edku, Egypt. Egyptian Journal of Aquatic Biology and Fish., 17(1): 101112.

SAS (1998). Statistics, SAS Institute Inc.

Scholz, N.L.; Truelove, N.K.; French, B.L.; Berejikian, B.A.; Quinn, T.P.; Casillas, E. and Collier, T.K. (2000). Diazinon disrupts antipredator and homing behaviors in 
chinook salmon (Oncorhynchus tshawytscha). Can. J. Fish. Aquat. Sci., 57: 19111918.

Sun, D.; Chen, Q.; He, N.; Diao, P.; Jia, L. and Duan, S. (2017). Effect of environmentally-relevant concentrations of nonylphenol on sexual differentiation in zebrafish: a multi-generational study. Scientific Reports, 7: 1-8.

Uguz, C.; Iscan, M.; Erguven, A.; Isgor, B. and Togan, I. (2003). The bioaccumulation of nonyphenol and its adverse effect on the liver of rainbow trout (Onchorynchus mykiss). Environmental Research, 92: 262-270.

Webster, L.; Roose, P.; Bersuder, B.; Kotterman, M.; Haarich, M. and Vorkamp, K. (2013). Determination of polychlorinated biphenyls (PCBs) in sediment and biota. ICES Techniques in Marine Environmental Sciences (page 4), No. 53, pp. 18.

\section{ARABIC SUMMARY}

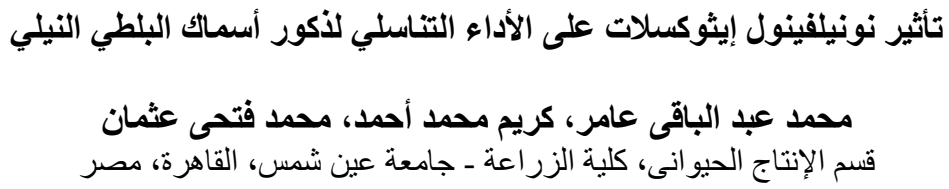

كان الهدف من هذه الدراسة هو التحقيق في التأثير الضار للأستروجين البيئى (النونيلفينول، شبيه الأستروجين)،

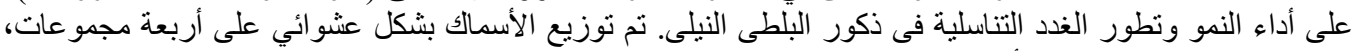

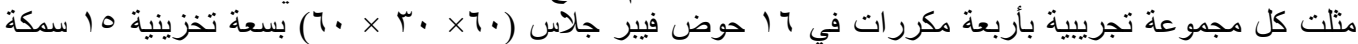

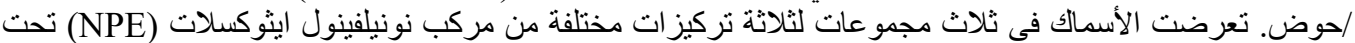

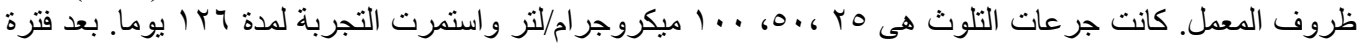

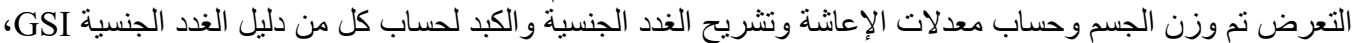

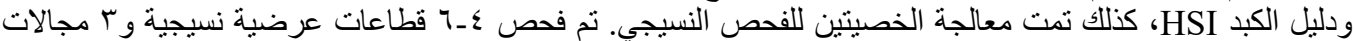

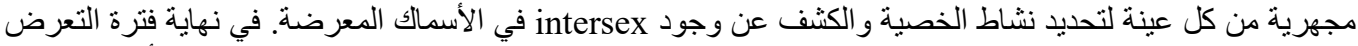

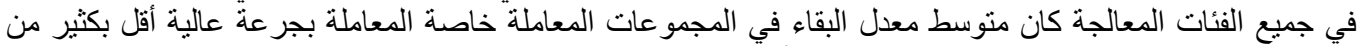

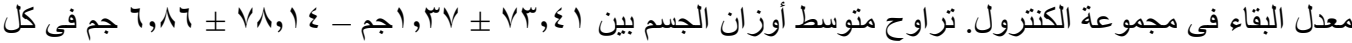

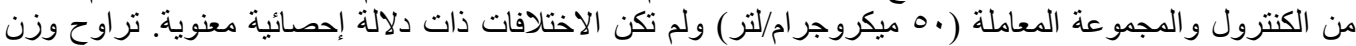

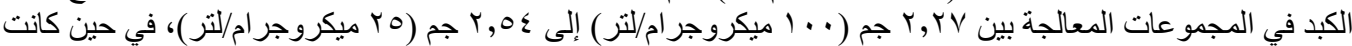
القيمة فى مجمو عة الكنترول

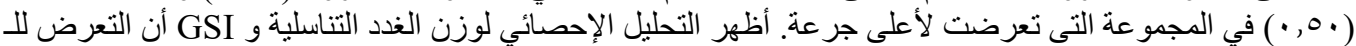
NP

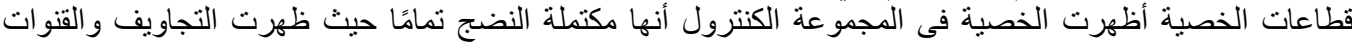

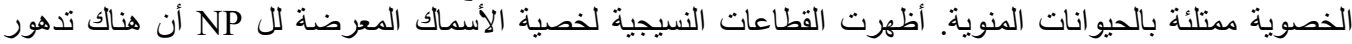

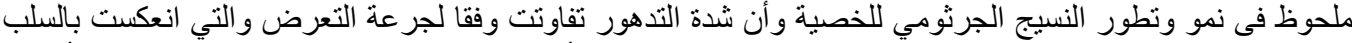

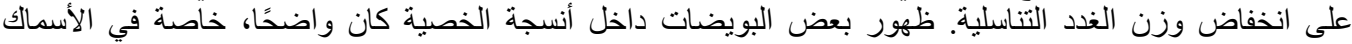

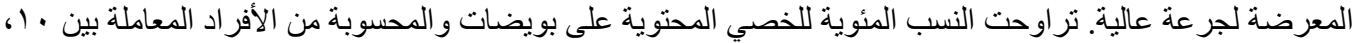

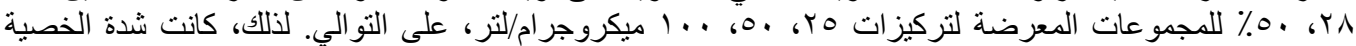

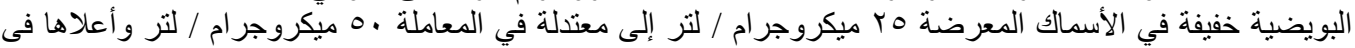

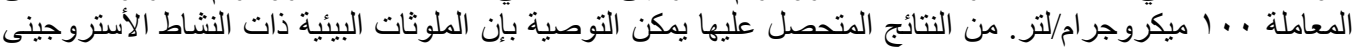

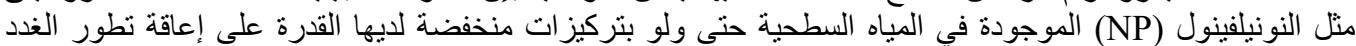
التناسلية وتكاثز الأسماك البرية والمستينز 